\title{
Experimental characterization of a PEM fuel cell for marine power generation
}

\author{
Andrea Pietra ${ }^{1,2 *}$, Marco Gianni ${ }^{1,2}$, Nicola Zuliani ${ }^{2}$, Stefano Malabotti ${ }^{3}$, Rodolfo Taccani ${ }^{2}$. \\ ${ }^{1}$ Merchant Ship Division, Fincantieri S.p.A., Trieste, Italy \\ ${ }^{2}$ Department of Engineering and Architecture, University of Trieste, Trieste, Italy \\ ${ }^{3}$ CEnergy, Trieste, Italy;
}

\begin{abstract}
This study is focused on the possible application of hydrogen-fed PEM fuel cells on board ships. For this purpose, a test plant including a $100 \mathrm{~kW}$ generator suitable for marine application and a power converter including a supercapacitor-based energy storage system has been designed, built and experimentally characterised. The plant design integrates standard industrial components suitable for marine applications that include the technologies with the highest degree of maturity currently available on the market. Fuel Cell generator and power converter have been specifically designed by manufacturers to fit the specific plant needs. The experimental characterisation of the plant has been focused on the evaluation of the efficiency of the single components and of the overall system. Results shows a PEM fuel cell efficiency of $48 \%$ (when all auxiliaries are included) and an overall plant efficiency, including power conditioning, of about $45 \%$. From load variation response tests, the fuel cell response time was maximum 2 seconds without supercapacitors and increased up to 20 seconds with supercapacitors connected, reducing the stress on the fuel cell generator. Experimental results confirm that PEM fuel cells, when supported by a suitably sized energy storage system, represent a viable technical solution for zero-emission power generation on board ships.
\end{abstract}

\section{Introduction}

International maritime transport accounts for about $2 \%$ to $3 \%$ of global Green House Gas (GHG) emissions. Also, in 2015 , shipping was responsible for almost $13 \%$ of the total GHG emission from transportation in the European Union (EU) [1]. According to the fourth International Maritime Organization (IMO) GHG Study, emissions have increased of almost $10 \%$ between 2012 and 2018 as a result of the growth in shipping activities. This study also highlights a sharp increase in short-lived climate pollutants, like methane and black carbon [2]. In the next years, shipping is expected to grow and thus its emissions are expected to increase up to $50 \%$ by 2050 if no proactive actions will be put in place [1]. For this reason, IMO has set a 50\% reduction target for the global shipping sector by 2050 and a $40 \%$ reduction target for emissions per transport unit by 2030 and a $70 \%$ reduction target by 2050 in order to reach zero emissions from international shipping as soon as possible by the end of this century. Innovative technologies, carbon-free fuels and efficiency gains are paramount for reducing maritime transport GHG emissions. In this context Proton Exchange Membrane (PEM) fuel cells are considered a novel technology even if they have been employed since 1960s especially for aerospace applications. This type of generator requires high purity hydrogen as fuel and therefore it can be considered a key enabling technology for carbon-free fuels. There have been some niche applications of PEM fuel cells in the maritime sector during last years, mainly as submarine's Air Independent Propulsion (AIP) system or small demonstration projects. Starting from 1980s, PEM fuel cell based AIP fuelled by hydrogen has been tested on board submarines. The nominal power installed has progressively increased during the years reaching a maximum of $300 \mathrm{~kW}$ on board class U-212A submarines developed for German and Italian Navies since 2002 [3]. Then, in 2003, a system based on the same technology has been installed on the Autonomous Underwater Vehicle (AUV) Urashima by the Japan Agency for Marine Earth Science and Technology. The PEM fuel cell power installed as main source of power on Urashima was limited to $4 \mathrm{~kW}$ and integrated with a lithium-ion rechargeable battery storage system [4-5]. Small but successful applications of PEM fuel cell powered passenger boats have been developed starting from the beginning of the $21 \mathrm{st}$ century. The most noteworthy project in such field are: the Duffy-Herreshoff DH 30 water-taxi developed in 2003 for operations in San Francisco bay $(3 \mathrm{~kW})$, the project Xperiance NX hydrogen developed in 2006 in Netherlands $(1.2 \mathrm{~kW})$, the ZemShip project operated in Hamburg, Germany between 2008 and 2010 (2x $48 \mathrm{~kW})$ [6] and Nemo H2 project, which run from 2008 to 2011 in Amsterdam, Netherlands $(60 \mathrm{~kW})$ [7]. Since these first applications, projects were focused on system's overall energy efficiency. For example, on ZemShip project, different energy management systems have been tested in order to evaluate the best possible operative solutions to minimise hydrogen fuel consumption and fuel cells degradation [8]. In more recent years, other projects regarding maritime utilisation of PEM fuel cells fed by hydrogen have not yet passed from the design phase to the building one, like the SF-Breeze and Zero-V projects, both from Sandia National Laboratories [9-10]. In 2018, Swedish-Swiss company $\mathrm{ABB}$ and Canadian Ballard Power Systems have announced to have signed a Memorandum of Understanding $(\mathrm{MoU})$ to design, develop and validate a 3 
MW PEM fuel cell power generation system specifically for marine applications [11]. At the moment of the development of this paper, no real application or details about the design and the validation of the ABB-Ballard PEM power system has been disclosed to the public. All these studies and project did not publish any significant experimental result about efficiency, transient load response and procedures for marine application classification. One of the main problems that naval engineers meet during their effort to decarbonise ships, is the lack of recognised international standards or guidelines for testing, modelling and certifying a fuel cell and all its related equipment. As far as the characterization of fuel cell systems is concerned, the availability of sources represents a further obstacle to ship designers. Among the researches available on this topic, the study [12] describes a PEM fuel cell's polarisation curve measurement and the statistical analysis of tests performed on this kind of power generator varying different parameters like temperature, pressure, flows of all fuel cell's interfaces and ambient conditions. Another report describes the experimental characterisation of a 1.2 $\mathrm{kW}$ PEM fuel cell and the modelling of its performances [13]. In order to improve efficiency, increase lifetime and reduce cost of PEM fuel cells for automotive market, Swiss Federal Office of Energy developed a time dependent numerical model [14]. An analysis of potential application of fuel cells in ferries and cruise ship can be found in [15] and [16]. Since the beginning of this project, authors have focused their work in developing a modular and easily scalable PEM power plant suitable for marine application. The elementary unit of this system is a 100 $\mathrm{kW}$ PEM fuel cells based power plant which has been designed, built and experimentally characterised. All components are able to withstand the harsh on board conditions, such as strong mechanical and environmental stresses (salty atmosphere, vibrations, inclinations, etc) and have been designed minimising their weight and volume. In particular, this power plant has been designed to be easily integrated on board minimising interfaces with systems already available on a ship. Also, this generation system is independent since has a dedicated cooling system without any impact on machinery spaces. Power converter which interfaces the fuel cell power plant with the onboard existing electrical network has been specifically designed by manufacturer to fit specific plant needs minimising conversion stages and including a supercapacitor-based energy storage system. The supercapacitors have been included in order to improve the system response to load change and, at the same time, reduce fuel cell degradation conditions that can arise when high load change are applied [17]. Considering the state of the art of the regulatory framework and the most recent literature available, the authors tested a marineready power generation plant following test methods and procedures which are currently not used for marine applications, bringing a useful contribution to the possible wider employment of PEM fuel cells and hydrogen on board ships. Authors have employed the international recognised standards IEC 62282-3-200 [18] and the European Community testing procedure document Test Module PEFC ST 5-3 [19]. In this work, authors have summarised experimental results obtained by tests carried out on the PEM power plant provided with field instrumentation and a dedicated automation system.

\section{Test plant}

The investigated test plant, shown in Fig. 1, consists of:

- a 200 bar g, 16 cylinders storage system of about $128 \mathrm{Nm}^{3}$ of hydrogen capacity;

- a $100 \mathrm{~kW}_{\mathrm{el}}$ PEM fuel cell generator (2 strings in parallel, each composed of 6 stacks in series, 1152 cells in total);

- a DC/AC power converter including a supercapacitor-based energy storage;

- an electronic load bank;

- a fuel cell dry cooler;

- an electric board and a control system

The fuel cell is a commercially available generator fed with pure hydrogen at a pressure of about 4 bar g. Process air entering the stacks is provided by means of an internal centrifugal blower. Air is filtered before entering the fuel cell. The DC power produced by the fuel cell is converted to a three phase $440 \mathrm{~V}$ AC power by means of a DC/AC power converter. This equipment includes a supercapacitor-based energy storage system to improve the dynamic behaviour of the fuel cell. The AC power is delivered to an electronic load bank, whereas the fuel cell thermal power is dissipated by means of a dry cooler. All the Balance Of Plant (BOP) devices, such as cooling circuit water pump and dry cooler, as well as the fuel cell internal ancillaries and overall plant control system are electrically powered by a dedicated electric board.

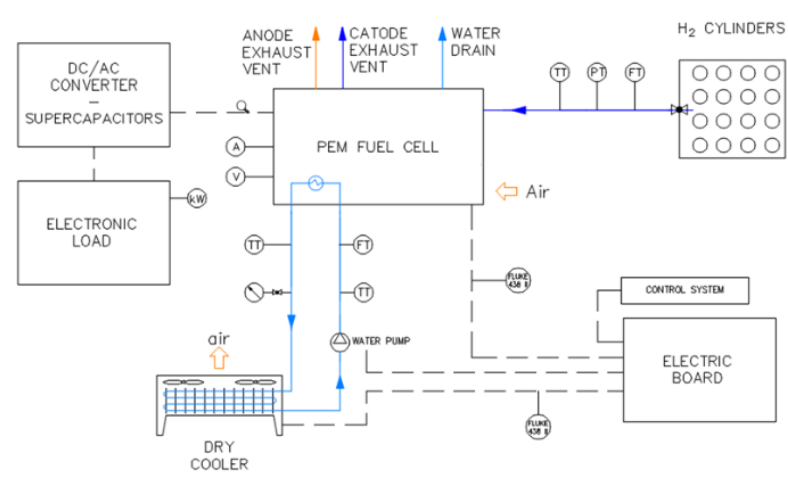

Fig. 1. P\&ID of the investigated test plant.

Table 1. System efficiency test: gross and net fuel cell and system electrical efficiency at $100 \%$ and $50 \%$ fuel cell nominal power.

\begin{tabular}{|c|c|c|c|c|}
\hline FC power & FC gross el. eff. & FC net el. eff. & System gross el. eff. & System net el. eff. \\
\hline $100 \%$ & $54,5 \%$ & $47,8 \%$ & $52,2 \%$ & $45,3 \%$ \\
\hline $50 \%$ & $58,5 \%$ & $47,5 \%$ & $56,6 \%$ & $45,6 \%$ \\
\hline
\end{tabular}




\section{Experimental analysis and results}

In order to investigate the performance of the system the following tests have been carried out:

- Fuel cell and system electrical efficiencies evaluation;

- fuel cell polarization curve plotting;

- $\quad$ system start-up and shut-down characterization;

- discharge water quality test;

- fuel cell electric load response analysis;

- load cycle test;

- $\mathrm{DC} / \mathrm{AC}$ converter characterization.

\subsection{Metrological characteristics of main instrumentation}

The accuracy and repeatability of the main instruments used to characterise the test plant are shown in Table 2.

Table 2. Metrological characteristics of main instrumentation.

\begin{tabular}{|c|c|c|}
\hline Component & Feature & Value \\
\hline $\begin{array}{c}\mathrm{H}_{2}, \text { thermal mass } \\
\text { flowmeter }\end{array}$ & $\begin{array}{c}\text { Accuracy } \\
\text { Repeatability }\end{array}$ & $\begin{array}{c} \pm 0.5 \% \mathrm{Rd} \text { plus } \pm 0.1 \% \\
\mathrm{FS} \\
<0.2 \% \mathrm{Rd}\end{array}$ \\
\hline $\begin{array}{c}\mathrm{H}_{2} \text { piezoresistive } \\
\text { pressure sensor }\end{array}$ & $\begin{array}{c}\text { Accuracy } \\
\text { Repeatability }\end{array}$ & $\begin{array}{c} \pm 0.50 \% \mathrm{FS} \\
<0.1 \% \mathrm{FS}\end{array}$ \\
\hline $\begin{array}{c}\text { BoP power } \\
\text { Portable network } \\
\text { analyser }\end{array}$ & Accuracy & $\pm 1 \% \pm 10$ counts \\
\hline FC voltage & Accuracy & $<1 \%$ \\
\hline FC current & Precision class & 1 \\
\hline
\end{tabular}

\subsection{Fuel cell and system electrical efficiency evaluation}

Fuel Cell (FC) and system electrical efficiencies have been calculated at $100 \%$ and $50 \%$ nominal power $(100$ $\mathrm{kW}_{\text {el }} \mathrm{DC}$ ) referring to hydrogen Lower Heating Value (LHV) equal to $120 \mathrm{MJ} / \mathrm{kg}$. Table 1 shows gross and net FC and system electrical efficiency at $100 \%$ and $50 \%$ nominal power.

Fuel cell gross electrical efficiency has been defined as:

$$
\eta_{F C_{-} \text {gross }}=\frac{P_{\text {elFC }}}{P_{\text {in }}} \cdot 100=[\%]
$$

Fuel cell net electrical efficiency has been calculated according to the formula indicated in IEC 62282-3-200:

$$
\eta_{F C_{-} \text {net }}=\frac{P_{\text {elFC }}-P_{\text {elin }}}{P_{\text {in }}} \cdot 100=[\%]
$$

Similarly, the system gross and net electrical efficiencies has been defined as:

$$
\begin{gathered}
\eta_{e l \_g r o s s}=\frac{P_{e l S Y S}}{P_{\text {in }}} \cdot 100=[\%] \\
\eta_{e l \_n e t}=\frac{P_{e l S Y S}-P_{e l i n}}{P_{\text {in }}} \cdot 100=[\%]
\end{gathered}
$$

The description of the symbols used in equations (1) to (4) are listed in Table 3. Fuel cell electrical efficiency is in line with data declared by other stationary systems fuel cell producers. The difference between the FC gross and net electrical efficiency is higher at $50 \%$ nominal power output. This is due to the BOP and ancillaries power consumption, which increases less than linearly with respect to the FC power output.

Table 3. Description of the symbols used in equation (1) to (6).

\begin{tabular}{|c|l|c|}
\hline Symbol & Description & Unit \\
\hline$P_{\text {elFC }}$ & FC DC power output & $\mathrm{kW}_{\mathrm{el}}$ \\
\hline$P_{\text {elSYS }}$ & System AC power output & $\mathrm{kW}$ \\
\hline$P_{\text {el }}$ & Fuel power input on LHV basis & $\mathrm{kW}$ \\
\hline$P_{\text {elin }}$ & BOP AC input power & $\mathrm{kW}$ \\
\hline
\end{tabular}

\subsection{Fuel cell polarization curve plotting}

FC polarization curve has been plotted following the guidelines included in the European Community (EC) Joint Research Centre test module PEFC ST 5-3 [19].

Table 4. Load bank power set point imposed for measuring the fuel cell polarization curve.

\begin{tabular}{|c|c|}
\hline \multirow{2}{*}{$\begin{array}{c}\text { Set point } \\
\text { number }\end{array}$} & $\begin{array}{c}\text { Load bank } \\
\text { power }\end{array}$ \\
\cline { 2 - 2 } & $\mathbf{k W}$ el \\
\hline $\mathbf{1}$ & 5 \\
\hline $\mathbf{2}$ & 10 \\
\hline $\mathbf{3}$ & 15 \\
\hline $\mathbf{4}$ & 20 \\
\hline $\mathbf{5}$ & 25 \\
\hline $\mathbf{6}$ & 30 \\
\hline
\end{tabular}

\begin{tabular}{|c|c|}
\hline \multirow{2}{*}{$\begin{array}{c}\text { Set point } \\
\text { number }\end{array}$} & $\begin{array}{c}\text { Load bank } \\
\text { power }\end{array}$ \\
\cline { 2 - 2 } & $\mathbf{k W}$ el \\
\hline $\mathbf{7}$ & 40 \\
\hline $\mathbf{8}$ & 50 \\
\hline $\mathbf{9}$ & 60 \\
\hline $\mathbf{1 0}$ & 70 \\
\hline $\mathbf{1 1}$ & 80 \\
\hline $\mathbf{1 2}$ & 93 \\
\hline
\end{tabular}

The polarization plotting process requires that the supercapacitors are charged and then that the fuel cell gets to its operational temperature. Fig. 2 shows fuel cell and system AC power output versus time during fuel cell polarization curve test. On the left side of Fig. 2 it is possible to observe the peak power delivered by the fuel cell to charge the supercapacitors. Then the fuel cell heats up delivering about $40 \mathrm{~kW}_{\text {el }}$ DC power. Fuel cell system warming phase lasts about 25 minutes. After the fuel cell has warmed up, the procedure for plotting of the polarization curve is started by increasing first and then decreasing the power absorbed by the load bank in steps, as indicated in Table 4.

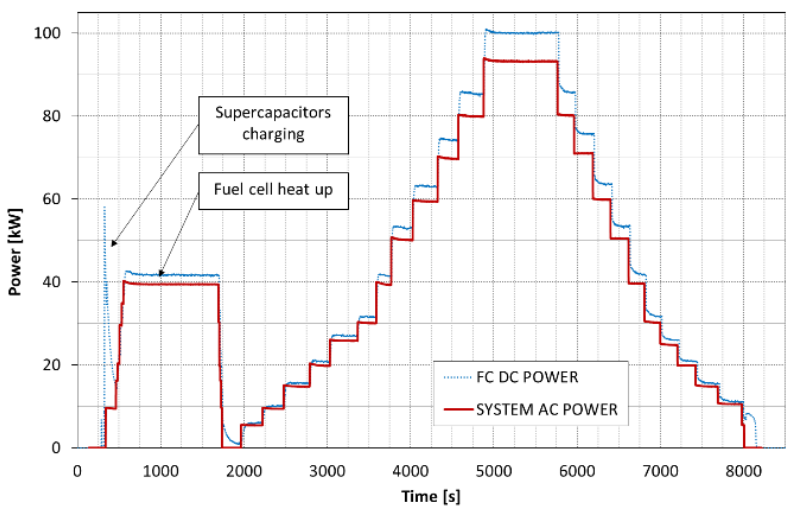

Fig. 2. Fuel cell and system power output versus time. 
Fig. 3 shows the fuel cell polarization curve recorded during the test. In the same figure the FC DC power variation with current is presented. Fuel cell polarization curve is in line with producer's data. Nominal power is delivered at about 250 A. At this operating point, considering that each fuel cell system consist of 2 string connected in parallel of 6 stacks in series and that the total number of cells is 1152 , the single cell voltage is about $0.7 \mathrm{~V}$. The data recorded for the polarization curve plotting allows to calculate also the FC and system electrical efficiency at different FC operating point. Fig. 4 shows FC and system gross and net electrical efficiencies variation at different $\mathrm{FC}$ power. It is possible to observe that FC and system gross electrical efficiencies decrease as power increase while $\mathrm{FC}$ and system net electrical efficiencies increase with power. As already mentioned in section 3.1, this behaviour is due to the higher influence of BOP power consumption at low loads. The highest FC gross electrical efficiency (about 60\%) is reached at $30 \%$ nominal load. System net electrical efficiency remains almost constant from about $60 \%$ to $100 \%$ fuel cell power.

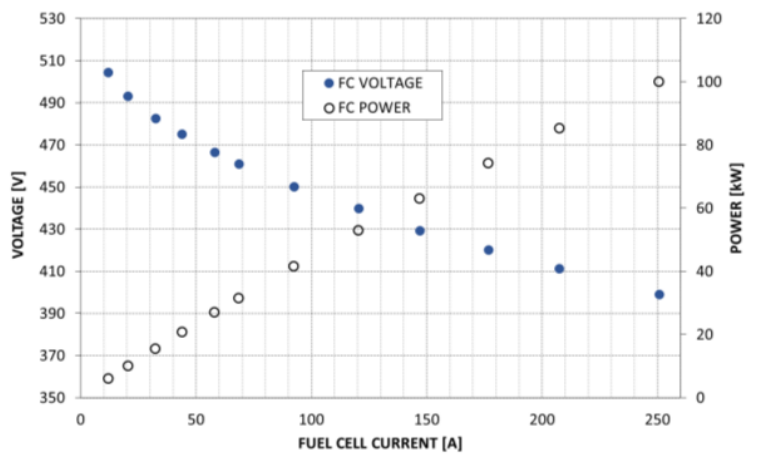

Fig. 3. Fuel cell voltage and power variation with current.

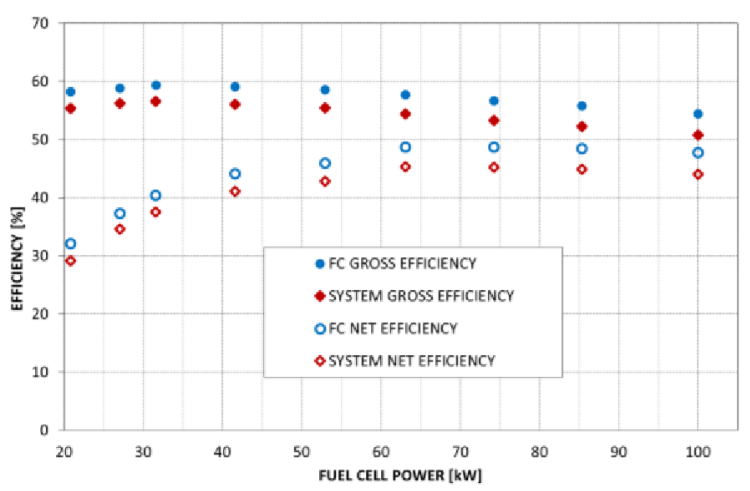

Fig. 4. Fuel cell and system gross and net electrical efficiency.

\subsection{System start-up and shut-down characterization}

System start-up and shut-down characterization test was developed to investigate energy and fuel consumption during these operational phases. In order to improve fuel cell expected life, the system is being flushed with hydrogen every time it is started or shut-down. In both cases hydrogen is discharged in atmosphere. An evaluation of the discharged hydrogen volume is essential to allow the calculation of the extension of any dangerous areas onboard, as required by Classification Societies. This parameter is also fundamental for the proper sizing of the hydrogen storage system. During the same test the BOP energy consumption and power demand were recorded as well in order to compare them with the ship power and energy availability. For the purpose of the test, the start-up period has been considered as the time interval between the issuing of the start signal and the reaching of a stable $15 \mathrm{~kW}_{\mathrm{el}} \mathrm{AC}$ power output. Similarly, the shutdown period has been considered as the time interval between load disconnection and the interruption of hydrogen consumption. In Table 5 and Table 6 hydrogen consumption, average and peak BOP electric power consumption and BOP electric energy demand at system start-up and shut-down are recorded. Total hydrogen consumption at start-up is $0.33 \mathrm{Nm}^{3}$, while hydrogen consumption at shut-down is $0.24 \mathrm{Nm}^{3}$. Maximum recorded peak BOP consumption is equal to $10 \mathrm{~kW}_{\mathrm{el}}$.

Table 5. Hydrogen consumption, average and peak BOP electric power consumption and BOP electric energy demand at system start-up.

\begin{tabular}{|r|c|c|}
\hline & Unit of measure & Value \\
\hline Time & $\mathrm{s}$ & 120 \\
\hline Hydrogen consumption & $\mathrm{Nm}^{3}$ & 0.33 \\
\hline Average BOP consumption & $\mathrm{kW}_{\mathrm{el}}$ & 3.3 \\
\hline Peak BOP consumption & $\mathrm{kW}_{\mathrm{el}}$ & 10 \\
\hline BOP electric energy demand & $\mathrm{kWh}$ & 0.11 \\
\hline
\end{tabular}

Table 6. Hydrogen consumption, average and peak BOP electric power consumption and BOP electric energy demand at system shut-down.

\begin{tabular}{|r|c|c|}
\hline & Unit of measure & Value \\
\hline Time & $\mathrm{s}$ & 175 \\
\hline Hydrogen consumption & $\mathrm{Nm}^{3}$ & 0.24 \\
\hline Average BOP consumption & $\mathrm{kW}_{\mathrm{el}}$ & 3.8 \\
\hline Peak BOP consumption & $\mathrm{kW}_{\mathrm{el}}$ & 9.6 \\
\hline BOP electric energy demand & $\mathrm{kWhel}$ & 0.19 \\
\hline
\end{tabular}

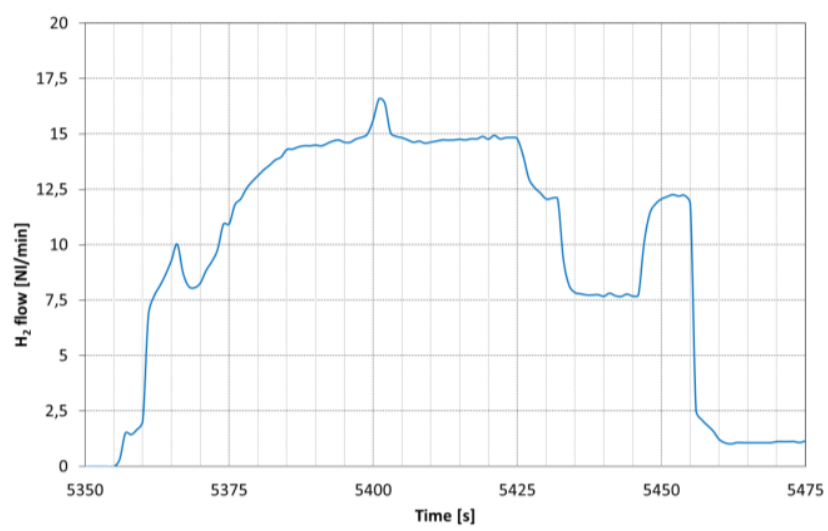

Fig. 5. System start-up: hydrogen flow rate variation with time.

Fig. 5 and Fig. 6 show hydrogen flow rate variation at start-up and shut-down respectively. It is possible to observe that the highest peak flow rate was measured at system shut-down and is higher than $25 \mathrm{Nl} / \mathrm{min}$. Hydrogen flow peaks are due to the fuel cell manufacture's control strategy that aims to remove every unwanted residue from the anode side before the fuel cell shuts down. 


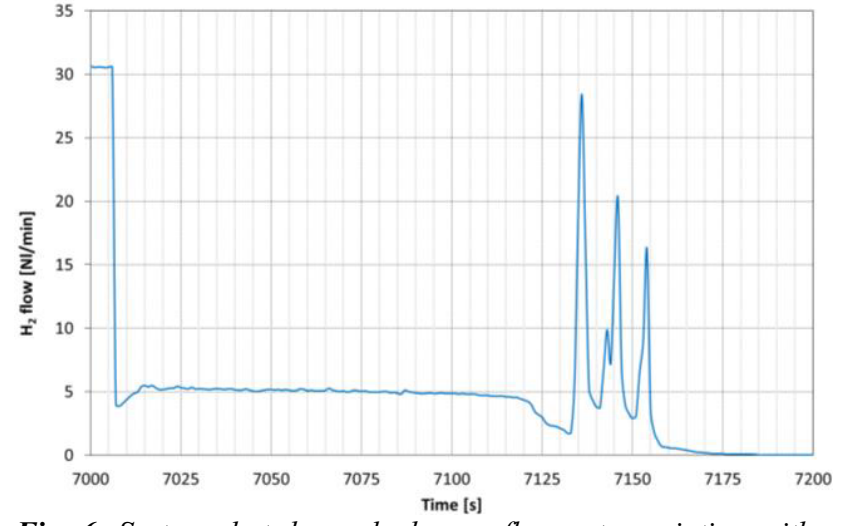

Fig. 6. System shut-down: hydrogen flow rate variation with time at system shut-down.

\subsection{Discharge water quality test}

This test was performed for measuring the quality of water discharged from the fuel cell in order to verify the possibility to collect this excess of product water into the onboard grey water collecting system. The test was carried out by analysing the water taken from the system internal process tank. As expected, the water analysis has shown that the fuel cell produced water can be considered demineralized water except for the presence of negligible quantities of iron, lead, zinc and nickel, probably originating from the cooling system pipes materials. Concentration of such contaminants is lower than values given in a study focused on the impact of grey water discharge in the Baltic Sea [20] and others stated in a document issued by United States Environmental Protection Agency [21].

Table 7. FC electrical load response time and FC delivered power for different load power variations. Supercapacitors connected.

\begin{tabular}{|c|c|c|c|}
\hline \multicolumn{2}{|c|}{ Load power variation } & \multirow{2}{*}{$\begin{array}{c}\text { FC response } \\
\text { time }\end{array}$} & \multirow{2}{*}{$\begin{array}{c}\text { FC } \\
\text { delivered power }\end{array}$} \\
\hline from & to & & \\
\hline $\mathbf{k W}$ & $\mathbf{k W}$ & $\mathbf{S}$ & $\mathrm{kW}$ \\
\hline 0 & 15 & - & 17.80 \\
\hline 15 & 45 & 19 & 47.75 \\
\hline 45 & 75 & 15 & 79.92 \\
\hline 75 & 93 & 10 & 99.09 \\
\hline 93 & 33 & 18 & 38.79 \\
\hline 33 & 15 & 21 & 20.12 \\
\hline 15 & 45 & 10 & 47.76 \\
\hline 45 & 75 & 15 & 79.66 \\
\hline 75 & 93 & 9 & 98.94 \\
\hline 93 & 33 & 20 & 40.22 \\
\hline 33 & 15 & 24 & 20.16 \\
\hline 15 & 45 & 10 & 47.77 \\
\hline 45 & 75 & 15 & 78.96 \\
\hline 75 & 93 & 10 & 99.07 \\
\hline 93 & 33 & 20 & 40.23 \\
\hline 33 & 15 & 22 & 20.29 \\
\hline 15 & 45 & 9 & 46.63 \\
\hline 45 & 75 & 17 & 79.66 \\
\hline 75 & 93 & 11 & 100.4 \\
\hline 93 & 33 & 21 & 38.98 \\
\hline 33 & 15 & 23 & 20.23 \\
\hline
\end{tabular}

Table 8. FC electrical load response time and FC delivered power for different load power variations. Supercapacitors disconnected.

\begin{tabular}{|c|c|c|c|}
\hline \multicolumn{2}{|c|}{ Load power variation } & \multirow{2}{*}{$\begin{array}{c}\text { FC response } \\
\text { time }\end{array}$} & \multirow{2}{*}{$\begin{array}{c}\text { FC } \\
\text { delivered power }\end{array}$} \\
\hline from & to & & \\
\hline $\mathbf{k W}$ & kW & $\mathbf{s}$ & kW \\
\hline 0 & 15 & - & 15.84 \\
\hline 15 & 45 & $\leq 1$ & 47.21 \\
\hline 45 & 75 & 2 & 80.78 \\
\hline 75 & 93 & $\leq 1$ & 99.65 \\
\hline 93 & 33 & $\leq 1$ & 33.34 \\
\hline 33 & 15 & $\leq 1$ & 15.83 \\
\hline 15 & 45 & 2 & 48.13 \\
\hline 45 & 75 & $\leq 1$ & 80.32 \\
\hline 75 & 93 & $\leq 1$ & 99.27 \\
\hline 93 & 33 & $\leq 1$ & 34.48 \\
\hline 33 & 15 & $\leq 1$ & 15.83 \\
\hline 15 & 45 & 2 & 48.10 \\
\hline 45 & 75 & $\leq 1$ & 80.36 \\
\hline 75 & 93 & $\leq 1$ & 99.26 \\
\hline 93 & 33 & 2 & 34.50 \\
\hline 33 & 15 & $\leq 1$ & 15.82 \\
\hline 15 & 45 & $\leq 1$ & 48.13 \\
\hline 45 & 75 & 2 & 80.22 \\
\hline 75 & 93 & $\leq 1$ & 99.24 \\
\hline 93 & 33 & $\leq 1$ & 34.52 \\
\hline 33 & 15 & $\leq 1$ & 15.80 \\
\hline
\end{tabular}

\subsection{Fuel cell electric load response analysis}

This test was performed for measuring the FC power response time, which is defined as the time interval necessary to reach a FC electric power output steady-state value starting from the moment in which a change of electric power output is started. The test has been carried out both with supercapacitor storage system connected and disconnected. For the purpose of the test, it has been chosen not to apply a load power increase higher that 30 $\mathrm{kW}_{\mathrm{el}}$ in order to preserve system integrity. Table 7 and Table 8 shows FC electrical load response time and FC delivered power with supercapacitor storage system connected and disconnected respectively. With supercapacitors connected, the longest FC response time was 24 seconds with a step load reduction from 33 to 15 $\mathrm{kW}_{\mathrm{el}}$. The shortest $\mathrm{FC}$ response time was 9 seconds and it was recorded with a step load increase from 15 to $45 \mathrm{~kW}_{\mathrm{el}}$ and from 75 to $93 \mathrm{~kW}_{\mathrm{el}}$. With supercapacitors disconnected, the longest $\mathrm{FC}$ response time was about 2 seconds. Fig. 7 and Fig. 8 show the fuel cell power variation during the $\mathrm{FC}$ electric load response test with supercapacitor storage system connected and disconnected respectively. Comparing Fig. 7 and Fig. 8 it is evident how the supercapacitor energy storage system integrated in the DC/AC converter smoothens the FC delivered power output. 


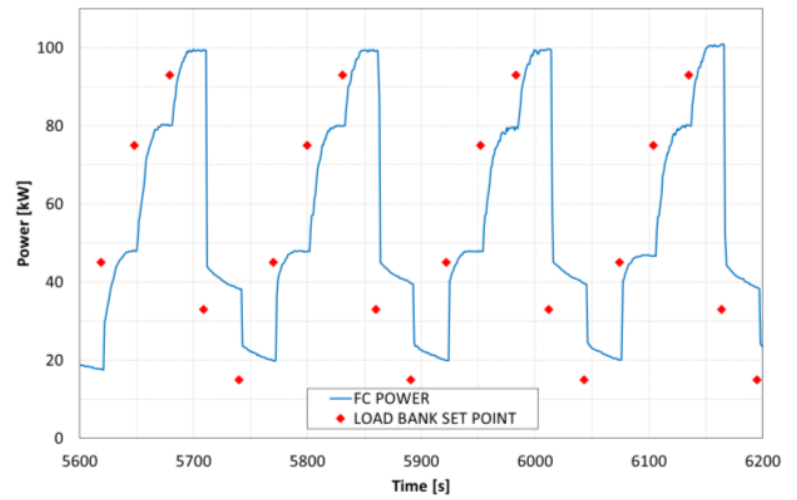

Fig. 7 Fuel cell power variation for the FC electrical load response time test with supercapacitor storage system.

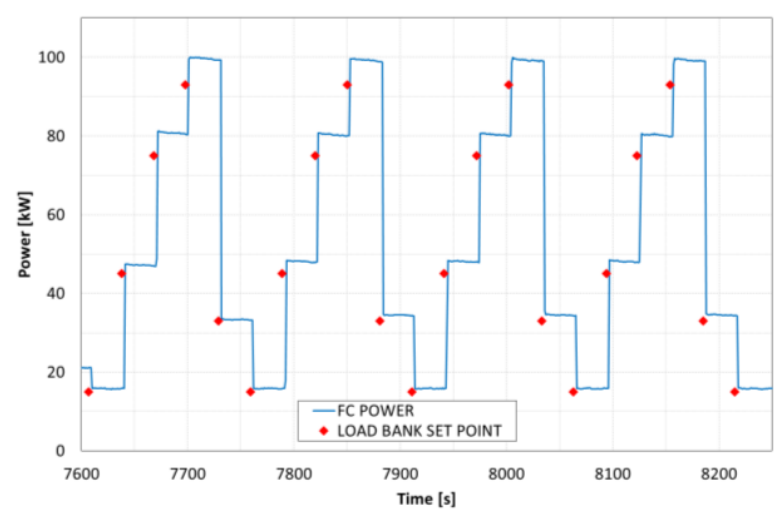

Fig. 8. Fuel cell power variation for the FC electrical load response time test without supercapacitor storage system.

\subsection{Load cycle test}

A load cycle test consisting in periodically changing the power required from the generator has been performed to evaluate the dynamic response of the generator when following a continuously variable load, i.e. a load cycle.

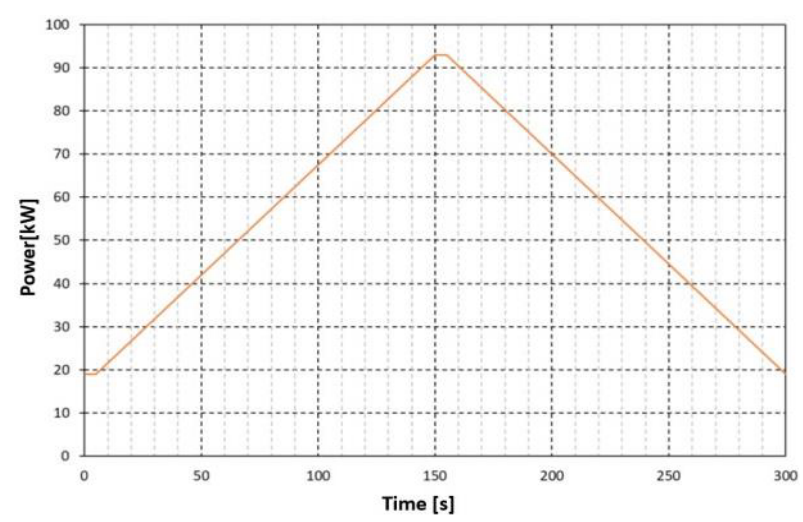

Fig. 9. Load cycle test: load profile applied at the load bank.

Load profile applied at the load bank had a triangular shape, with power output varying from a minimum value of $19 \mathrm{~kW}_{\mathrm{el}}$ to the load bank rated power $\left(93 \mathrm{~kW}_{\mathrm{el}}\right)$, as shown in Fig. 9. The load cycle has a period of 5 minutes. The test was carried out with the supercapacitors in operation. Fig. 10 shows the fuel cell delivered power variation during the load cycle test. The system is capable of following the proposed triangular-shaped load cycle without any issue.

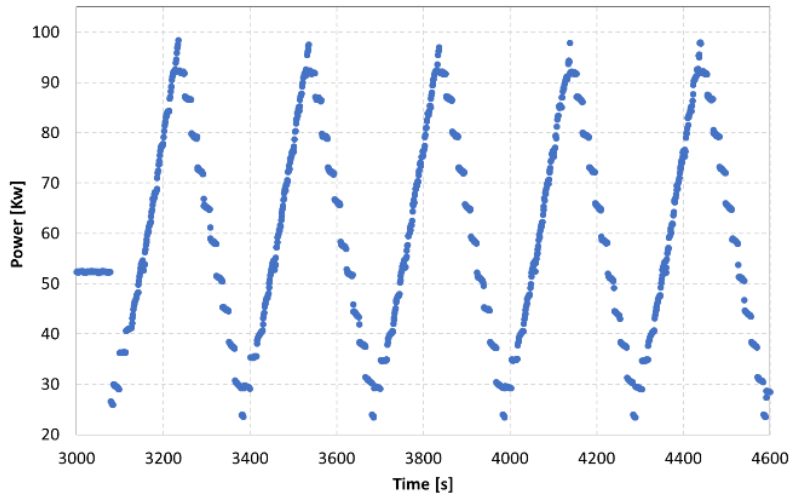

Fig. 10. Fuel cell delivered power variation during the load cycle test.

\subsection{DC/AC converter characterization}

The test for the characterization of the $\mathrm{DC} / \mathrm{AC}$ converter was carried on in order to:

- $\quad$ characterize the charging process of supercapacitors;

- $\quad$ evaluate the efficiency of DC/AC converter at different loads;

- $\quad$ analyse the system current and voltage behaviour at different power factors.

\subsection{Supercapacitors charging process characterization}

The characterization of the supercapacitor charging process aims to evaluate the supercapacitors voltage variation with time, the time required for charging them and the current and voltage at the fuel cell output during such process.

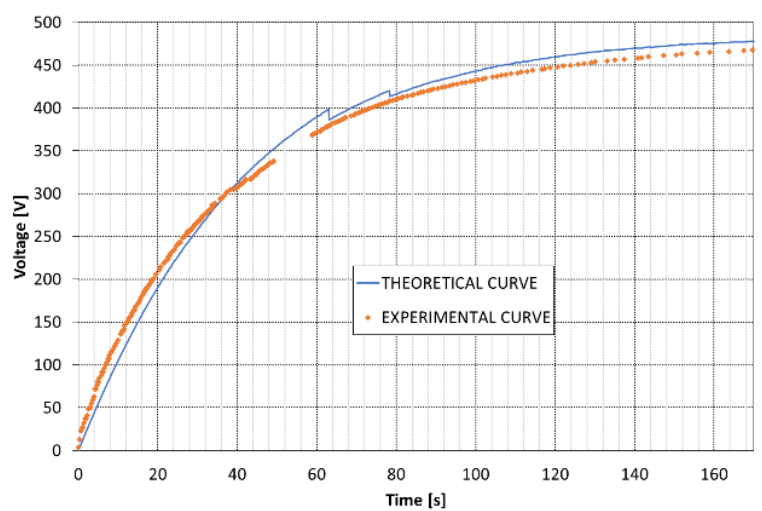

Fig. 11. Experimental and theoretical supercapacitors voltage variation with time.

In Fig. 11 is shown the measured supercapacitors voltage variation with time. In the same figure, the theoretical supercapacitors voltage variation with time of an equivalent Resistor-Capacitor (RC) circuit is also plotted. It is possible to observe a good correspondence between the experimental and the theoretical curves. The charging process is considered completed when the power delivered by the fuel cell is equal to the setting point of the load bank and the voltage reading across the supercapacitors is constant. It has been observed that the charging process takes about $175 \mathrm{~s}$. The final 
supercapacitors voltage is $470 \mathrm{~V}$. Fig. 12 shows fuel cell current and voltage variation with time during the supercapacitors charging period. Fuel cell voltage initially increases, then becomes stable at $470 \mathrm{~V}$. Instead, the fuel cell current decreases as supercapacitors charge. It is also possible to notice two discontinuities in the fuel cell current and voltage curves. These are due to the supercapacitors charging strategy adopted. At the beginning of the charging process the fuel cell delivers about $20 \mathrm{~kW}_{\mathrm{el}}$ to charge the supercapacitors. As the energy storage system is being charged, the power delivered by the fuel cell decreases. In order to avoid high fuel cell potential that can negatively affect fuel cell performance and that can accelerate degradation, a load is applied during the supercapacitors charging period.

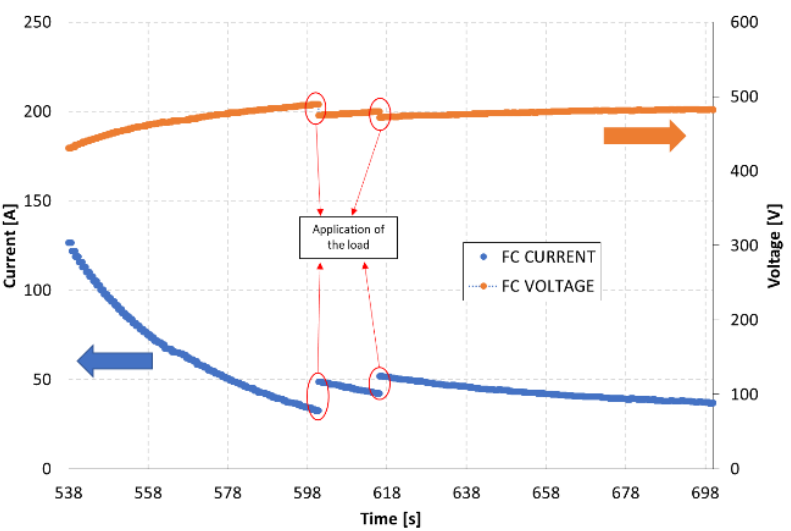

Fig. 12. Fuel cell current and voltage behaviour during the supercapacitors charging period.

\subsubsection{Converter efficiency evaluation}

In Table 9 conversion efficiency, converter average power and FC average power at two different load bank set points $\left(45 \mathrm{~kW}_{\mathrm{el}}\right.$ and $\left.80 \mathrm{~kW}_{\mathrm{el}}\right)$ are presented. Average values are calculated on a 10 minutes basis. Results show that the maximum conversion efficiency is reached at 45 $\mathrm{kW}_{\mathrm{el}}$ output and is equal to $96.2 \%$. Considering that the $\mathrm{DC} / \mathrm{AC}$ converter is a prototypal unit, this value could be further improved.

Table 9. Conversion efficiency, converter and FC average power at different load bank set point.

\begin{tabular}{|c|c|c|c|}
\hline $\begin{array}{c}\text { Load bank } \\
\text { set point }\end{array}$ & $\begin{array}{c}\text { Average FC } \\
\text { power }\end{array}$ & $\begin{array}{c}\text { Converter average } \\
\text { power }\end{array}$ & $\begin{array}{c}\text { Conversion } \\
\text { efficiency }\end{array}$ \\
\hline $\mathbf{k W}_{\mathrm{el}}$ & $\mathbf{k} \mathbf{W}_{\mathrm{el}}$ & $\mathbf{k W}_{\mathrm{el}}$ & $\mathbf{\%}$ \\
\hline 45 & 46.9 & 45.1 & 96.2 \\
\hline 80 & 85.5 & 81.2 & 94.9 \\
\hline
\end{tabular}

\subsubsection{System current and voltage behaviour at different power factors}

The power factor variation test was performed to evaluate the response of the system under real operating conditions, when a reactive electrical load component is present. The influence of the power factor variation on the power generation system behaviour is evaluated by measuring converter reactive power output and fuel cell power output when the power factor changes. The considered system load is $50 \mathrm{~kW}_{\mathrm{el}}$.

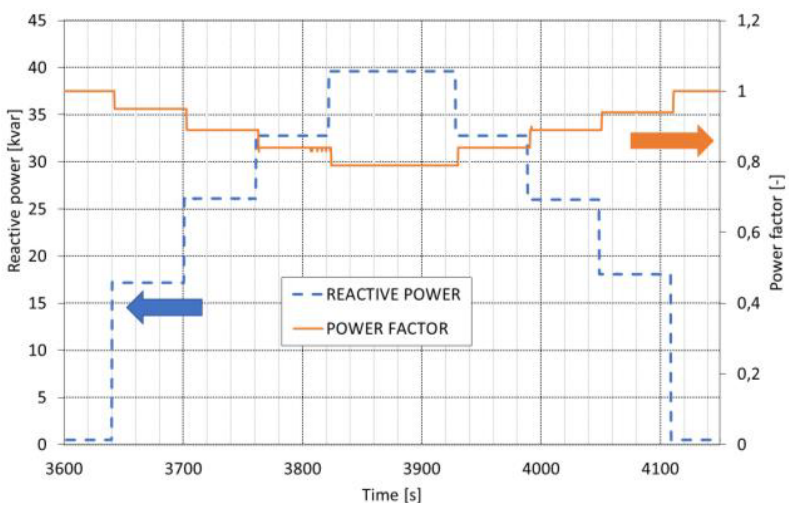

Fig. 13. Converter reactive power output variation as load bank power factor changes. Considered system load: $50 \mathrm{kWel}$

Fig. 13 shows converter reactive power output variation as power factor changes: converter reactive power increases up to $38.9 \mathrm{kvar}$ when power factor decrease to 0.8 . Fig. 14 shows FC power output and load bank power factor variation with time: as the power factor varies, the effect on the fuel cell is negligible, with small oscillation of the produced output power.

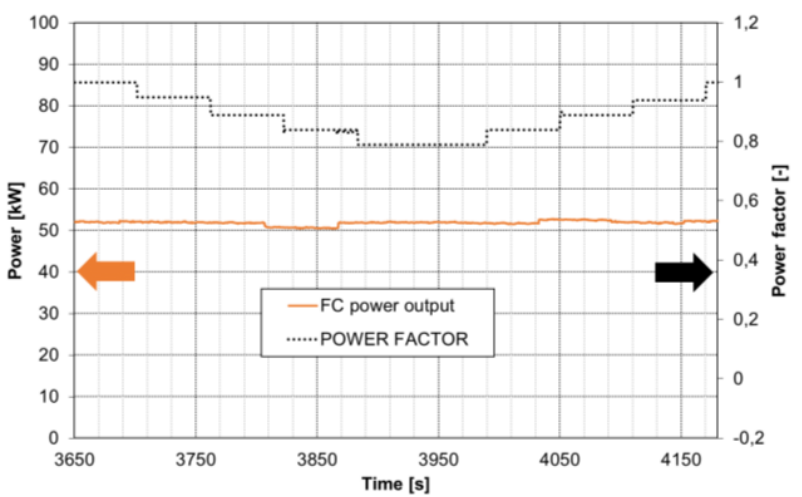

Fig. 14. FC power output and load bank power factor variation with time.

\section{Discussion and conclusion}

In the past years, applications of marine-ready PEM fuel cell based systems have been limited to niche vessels, like inland small passenger vessels or naval submarines, and in literature, very little experimental data is available especially regarding experimental characterization of marine-ready systems for seagoing vessel or cruise ships. In this work, in order to widen the knowledge on PEM fuel cell based generators suitable for such applications, a $100 \mathrm{~kW}_{\mathrm{el}}$ PEM fuel cell test plant including a power $\mathrm{DC} / \mathrm{AC}$ converter with a supercapacitors energy storage system, has been designed, built and experimentally characterized in order to ease the approval process for on board installation and the integration with the ship electrical system. The obtained data demonstrates that plant efficiency is comparable with commercial heavyduty systems. It has been also observed that, as expected, the system load response time is noticeably improved by the supercapacitors based energy storage that, at the same time reduces the stress on the fuel cell generator. 
Nevertheless, the PEM fuel cell generator still shows good response time even when supercapacitors are not activated. The analysis on the fuel cell start-up and shutdown procedures highlights that some hydrogen used to flush the fuel cells internal channels is discharged into the atmosphere. The largest volume of hydrogen is flushed at system start-up and is about $0.33 \mathrm{Nm}^{3}$. This value has to be taken into account in order to calculate the extension of any dangerous area that can arise at fuel cell anode exhaust on board of a ship, as required by Classification Societies. The DC/AC power converter and system startup analysis show that the time to recharge the supercapacitors is about $175 \mathrm{~s}$ and the time to warm up the fuel cell system is about 25 minutes. A BOP peak power of about $10 \%$ of the plant nominal power should be made available for the start-up. The load cycle test confirms the capability of the system to follow a cyclical load variation. However, further tests should be done in order to evaluate fuel cell degradation when a variable load is applied over a longer period of time, as it could happen on board of a ship. Authors are anyway confident that the already obtained data could help the process of integrating a PEM fuel cell based system on board of seagoing ships. The next step of the experimentation is the installation of the system on board for testing its response to the marine environment.

\section{$5 \quad$ References}

1. M. Pape for EPRS (European Parliamentary Research Service); decarbonising maritime transport: the EU prespective, 2020. Available at: https://www.europarl.europa.eu/RegData/etudes/BR IE/2020/659296/EPRS_BRI(2020)659296_EN.pdf ;

2. International Maritime Organisation, Fourth IMO Greenhouse Gas Study, 2020. Available at: https://wwwcdn.imo.org/localresources/en/OurWork /Environment/Documents/Fourth\%20IMO\%20GHG $\% 20$ Study $\% 202020 \% 20-\% 20$ Full\%20report $\% 20$ and $\% 20$ annexes.pdf;

3. J. B. Lakeman, D. J. Browning; The Role of Fuel Cells in the Supply of Silent Power for Operations in Littoral Waters. Proceedings of NATO RTO AVT Symposium on "Novel Vehicle Concepts and Emerging Vehicle Technologies", 47, 1-18, 2004;

4. T. Sawa, T. Aoki, I. Yamamoto et al.; Performance of the fuel cell underwater vehicle URASHIMA. Acoustic Science \& Technologies 26, 249-257, 2005;

5. T. Maeda, S. Ishiguro, K. Yokoyama et al.; Fuel Cell AUV "Urashima”. Mitsubishi Heavy Industries, Ltd. Technical Review Vol. 43 No. 1, 2006;

6. K. T. Hammou; One hundred passengers and zero emissions, 2008. Available at: https://webgate.ec. europa.eu/life/publicWebsite/project/details/2657 ;

7. EMSA, Study on the use of fuel cells in shipping, 01/2017. Available at: http://www.emsa.europa.eu/ publications/download/4545/2921/23.html;

8. A. Bassam, S. R. Turnock, A. Phillips, P. Wilson; Development of a multi-scheme energy management strategy for a hybrid fuel cell driven passenger ship.
International Journal of Hydrogen Energy 42, 2016. DOI: 10.1016/j.ijhydene.2016.08.209

9. J. W. Pratt, L. E. Klebanoff; Feasibility of the SFBREEZE: a Zero-Emission, Hydrogen Fuel Cell, High-Speed Passenger Ferry. Sandia National Laboratories, 2016;

10. L. E. Klebanoff, J. W. Pratt, R. T. Madsen et al.; Feasibility of the Zero-V: A Zero-Emission, Hydrogen Fuel-Cell, Coastal Research Vessel. Sandia National Laboratories, 2018;

11. ABB press release on $27^{\text {th }}$ June 2018 , available online at: https://new.abb.com/news/detail/5360/abb-andballard-power-systems-to-jointly-develop-zero-emis sion-fuel-cell-power-plant-for-shipping-industry;

12. L. Placca, R. Kouta, D. Candusso, J. F. Blachot, W. Charon; Analysis of PEM fuel cell experimental data musing Principal Component Analysis and Multi linear regression. International Journal of Hydrogen Energy 35, 4582-4591, 2010. DOI: ff10.1016/ j.ijhydene. 2010.02.076

13. I. San Martìn, A. Ursùa, P. Sanchis; Modelling of PEM Fuel Cell Performance: Steady-State and Dynamic Experimental Validation. Energies 2014, 7; 670-700, 2014. DOI: doi:10.3390/en7020670

14. J. O. Schumacher, R. Herrendörfer for the Swiss Federal Office of Energy, ACTIF: Advanced CharacTerIsation of Fuel Cell Stacks for Automotive Applications, 2019. Available online at: https:// www.aramis.admin.ch/Default? DocumentID $=66024$ \&Load $=$ true

15. C., Dall'Armi, D. Micheli, R. Taccani, Comparison of different plant layouts and fuel storage solutions for fuel cells utilization on a small ferry, 2021

International Journal of Hydrogen Energy, 46(26), pp. 13878-13897.

16. M. Gianni, A. Pietra, R. Taccani, Outlook of future implementation of PEMFC and SOFC onboard cruise ships, Proceeding of Applied Energy Symposium (ICAE), 100RES, Pisa 29 October 2020.

17. 15. P.Pei, X. Yuan, J. Gou and P. Li, Dynamic Response during PEM Fuel Cell Loading-up, Materials 2009, 2, 734-748; doi:10.3390/ma2030734

18. International Electrotechnical Commission; IEC 62282-3-200:2015 Fuel Cell Technologies - Part 3200: Stationary Fuel Cell Power Systems Performance test methods;

19. European Commission Joint Research Centre; PEFC power stack performance testing procedure Measuring voltage and power as function of current density. Polarisation curve test method Test Module PEFC ST 5-3, 2013;

20. E. Ytreberg, M. Eriksson, I. Maljutenko et al.; Environmental impacts of grey water discharge from ships in the Baltic Sea. Marine Pollution Bulletin 152, 2020. DOI: https://doi.org/10.1016/j.marpolbul. 2020.110891

21. United States Environmental Protection Agency, Greywater Discharge from Vessels. 2011, available online at: https://www3.epa.gov/npdes/pubs/vgp_ graywater.pdf 